\title{
Hotel and Restaurant Taxes Role to the Local Original Revenue of Regency/City in South Sumatera
}

\author{
Sovi Julianda Wahya ${ }^{1}$ Sukmini Hartati ${ }^{1}$ Eka Jumarni Fithri ${ }^{1}$ Rita Martini ${ }^{1, *}$ \\ ${ }^{1}$ Accounting Department, Polytechnic State of Sriwijaya, Palembang 30139, Indonesia \\ ${ }^{*}$ Corresponding author. Email: ritamartini@polsri.ac.id
}

\begin{abstract}
This study aims to analyze the effect of the hotel tax and restaurant tax income to the local origianal revenue regency/city of in south sumatera fiscal year 2016 - 2020. The sample of this research includes 14 regions in South Sumatera. This sample was selected based on the purposive sampling method. This study uses multiple regression analysis. The data used in this study are secondary data with documentation as the data collecting techniques. This study indicate that the hotel tax has a positive and significant effect on local revenue. Restaurant tax has a positive and significant effect on local revenue. Simultaneously hotel tax and restaurant have a significant effect on local revenue.
\end{abstract}

Keywords: Tax, revenue, locally generated revenue

\section{INTRODUCTION}

Each region is required to increase Regional Original Income to finance its household affairs. This effort is aimed at improving the quality of public services in creating better governance [1]. In fulfilling every government financing and regional development through regional original revenue, the regional government is expected to be able to explore sources of revenue. UU No. 33/2004 concerning Fiscal Balance between the Central Government and Regional Governments, regional original income [2] is income earned by the regions which is collected based on regional regulations. Regional original income is sourced from regional taxes, regional levies, separated regional wealth management results and other legitimate regional original revenues. The four components are very important and each contributes to local revenue. The greater the role of regional original income in regional income is a reflection of the success or level of regional financial independence in financing the administration of government and regional development

Regency and city governments in South Sumatra province in an effort to develop and develop their regions have made efforts to increase sources of regional original income according to their potential. Realization of local revenue for districts/cities in South Sumatra Province fluctuates every year. There are 2 regencies that each year experience an increase, namely Banyuasin and Musi Banyuasin. Meanwhile, the other 12 regencies/cities experienced fluctuations. This indicates that there are still district/city governments that have not been optimal in optimizing revenue from existing resources in their respective regions [3].

Potential sources of local original income must be explored to the maximum in accordance with applicable provisions and regulations, including local taxes which are one of the main elements of local revenue sources. Tax revenue sourced from local revenue itself needs to be increased to support the development of regional autonomy. The greater the Regional Tax received will automatically increase the regional revenue. UU No. 28/2009 concerning Regional Taxes and Levies [4] describes that regional taxes and regional levies are an important source of regional income to finance the implementation of regional government. To improve services to the community [5], the government also provides an expansion of the object of regional taxes and regional levies, as well as providing discretion in setting rates.

UU No. 28/2009 distinguishes the types of local taxes in Indonesia which are divided into two [4], namely provincial taxes and district/city taxes. According to [6] when compared to the business sector, the source of local government revenue is relatively predictable and more stable, because the income is regulated by local regulations that are increasing and can be forced. Hotel tax and restaurant tax are types of regional taxes whose revenues are increasingly being considered by the existence of supporting components, namely the service, 
development and tourism sectors in regional development policies. The linkage between the tourism sector and the taxation sector is that in the tourism sector there are tourism supporting facilities such as tourist attractions, hotels and restaurants support facilities and the diversity of arts and culture. Each use of these tourist facilities is subject to tax to its users.

The number of hotels and restaurants is increasing every year. The availability of hotels and restaurants in regencies and cities in South Sumatra Province shows the level of investment attractiveness which shows the development of economic activity in South Sumatra and the opportunities it creates. Every remuneration provided by consumers will certainly bring in income for the regency/city government in the Province of South Sumatra in the form of regional taxes. Hotel taxes and restaurant taxes play an important role in increasing local revenue. The increase in the number of realized revenues cannot yet be used as a measure of the success of tax collection that has been carried out by the regency/city Government in South Sumatra. [7] stated that hotel and restaurant taxes have a positive and significant effect on local revenue. [8] stated that the hotel tax has a positive but not significant effect, while the restaurant tax only has a significant effect. This research contrasts with [9] and [9], that only hotel tax has a significant effect while restaurant tax has no effect on local revenue. From the results of previous studies, there is still no consistency between one researcher and another, either because of differences in location and the time period studied.

This research is devoted to data from 2016 to 2020 where Government Regulation Number 71 of 2016 concerning the addition of the capital of the Republic of Indonesia to the Capital of the Health Social Security Administration and Government Regulation Number 71 of 2020 concerning the addition of the capital of the Republic of Indonesia to the Capital of the Republic of Indonesia in the share capital of the PT Hutama Karya. The focus of this research is on the effect of hotel tax and restaurant tax on district/city local original revenue in South Sumatra Province in the 2016-2020 period.

\section{LITERATURE REVIEW RESEARCH HYPOTHESES}

AND

One measure of the success of tax collection can be done by analyzing the effect of local tax revenues on local revenue. For regions that have the potential for large hotel taxes, restaurant taxes and entertainment taxes, they will also play a big role in increasing the local original revenue of the regency/city government.

Hotel tax is a tax on services provided by the hotel. The object of hotel tax is the service provided by the hotel with payment, including supporting services as a completeness of the hotel which provides convenience and comfort, including sports and entertainment facilities. The subject and taxpayer of the hotel tax as referred to in [4] concerning regional taxes and regional levies, the tax subject is an individual or entity that makes payments to an individual or entity operating a hotel. Meanwhile, hotel taxpayers are individuals or entities operating hotels. In simple terms, hotel tax subjects are consumers who pay for and enjoy the services provided by hotel entrepreneurs. While the hotel taxpayer is a hotel entrepreneur who does work in the field.

UU No. 28/2009 concerning Regional Taxes and Regional Levies [4], restaurant tax is a tax on services provided by restaurants, while restaurants are facilities that provide food and/or drinks for a fee, which includes restaurants, cafeterias, canteens, bars, and including catering/catering services. The object of the restaurant tax which is the object of the restaurant tax is the service provided by the restaurant.

The services provided by the restaurant as intended include the sale of food and/or drinks consumed by the buyer, whether consumed at the service place. The subject and taxpayer of the restaurant as referred to in [4], the subject of the restaurant tax is an individual or entity that buys food and/or drinks from a restaurant. The restaurant taxpayer is an individual or entity that operates a restaurant. In accordance with [4], the restaurant tax rate is set at a maximum of $10 \%$. The principal amount of restaurant tax payable is calculated by transferring the restaurant tax rate to the tax base.

Accordance with [2], regional original revenue, is the income obtained from the Region which is collected based on the Regional Regulation in accordance with the regulation. legislation. The sources of local original revenue in accordance with [2] are sourced from:

\section{Local Tax}

2. Regional Retribution

3. Result of Segregated Wealth Management

4. Other Local Original Revenue.

\section{RESEARCH METHODOLOGY}

Type of research is causal associative with quantitative methods. In this study, the causal associative method was used to explain the effect of hotel tax, restaurant tax and entertainment tax on local original revenue in districts/cities in South Sumatra province. Furthermore, quantitative methods are used, in the form of financial reports covering the realization of local tax 
revenues and local revenue in 14 districts/cities in the province of South Sumatra. The dependent variable used in this study is Local Original Revenue (Y). The independent variables used in this study are Hotel Tax $\left(\mathrm{X}_{1}\right)$ and Restaurant Tax $\left(\mathrm{X}_{2}\right)$.

The population of this research is 14 districts/cities in South Sumatra province. The sampling method was carried out by purposive sampling, namely the way of taking samples based on certain considerations [11]. The sampling criteria are presented in table 1 .

Table 1. Research Sample Determination Criteia

\begin{tabular}{|c|l|c|}
\hline No. & \multicolumn{1}{|c|}{ Identifikasi } & Amount \\
\hline 1 & $\begin{array}{l}\text { District/City Government } \\
\text { Financial Reports in South } \\
\text { Sumatera Province that have been } \\
\text { audited by BPK in 2016-2020 }\end{array}$ & 17 \\
\hline 2 & $\begin{array}{l}\text { District/City Government } \\
\text { Financial Reports in South } \\
\text { Sumatera Province that have been } \\
\text { audited by BPK who do not have } \\
\text { complete LKPD during 2016 - } \\
\text { 2020 }\end{array}$ & \\
\hline 3 & $\begin{array}{l}\text { Regencies/Cities in South } \\
\text { Sumatera Province used as a } \\
\text { sample }\end{array}$ & 14 \\
\hline 4 & $\begin{array}{l}\text { Research year } \\
\text { Total Unit of Analysis }\end{array}$ & 70 \\
\hline &
\end{tabular}

Source: Data processed (2021)

Based on the criteria in table 1 , the number of regencies/cities that will be used as research samples is 14 (10 regencies and 4 cities) using 5 years of research, namely 2016-2020, the number of observation units for this research is 70 . then $82 \%$ of the total 17 population. The list of regencies/cities in the province of South Sumatra that was sampled in this study is shown in table 2 .

Table 2. Research Samples

\begin{tabular}{|c|l|}
\hline No & \multicolumn{1}{|c|}{ Kabupaten/Kota } \\
\hline 1 & Banyuasin \\
\hline 2 & Empat Lawang \\
\hline 3 & Lahat \\
\hline 4 & Muara Enim \\
\hline 5 & Musi Banyuasin \\
\hline
\end{tabular}

\begin{tabular}{|c|l|}
\hline No & \multicolumn{1}{|c|}{ Kabupaten/Kota } \\
\hline 6 & Ogan Ilir \\
\hline 7 & Ogan Komering Ilir \\
\hline 8 & Ogan Komering Ulu \\
\hline 9 & Ogan Komering Ulu Selatan \\
\hline 10 & Ogan Komering Ulu Timur \\
\hline 11 & Lubuk Linggau \\
\hline 12 & Pagar Alam \\
\hline 13 & Palembang \\
\hline 14 & Prabumulih \\
\hline
\end{tabular}

Source: Data processed (2021)

To analyze the effect of hotel tax and restaurant tax on local revenue, multiple linear regression analysis method is used with the formula:

$\mathrm{PAD}=\mathrm{a}+\mathrm{b} 1 \mathrm{PjH}+\mathrm{b} 2 \mathrm{PjR}+\mathrm{e}$

Information:

$\begin{array}{ll}\mathrm{PAD} & =\text { Local Original Income } \\ \mathrm{a} & =\text { Constant } \\ \mathrm{b} 1, \mathrm{~b} 2, \mathrm{~b} 3 & =\text { Multiple Regression coefficient } \\ \mathrm{PjH} & =\text { Hotel Tax } \\ \mathrm{PjR} & =\text { Restaurant Tax } \\ \mathrm{e} & =\text { Estimate Standard (error) }\end{array}$

The hypothesis proposed in this study is as follows:

$\mathrm{H}_{1}$ : Hotel tax revenue has an effect on local original income

$\mathrm{H}_{2}$ : Restaurant tax revenue has an effect to local original income

\section{RESULT AND DISCUSSION}

\subsection{Result}

The multiple linear regression equation in this study (based on the data in Table 3) is as follows:

PAD $=16,141+0,269$ Hotel Tax +0.184 Restaurant Tax $+\mathrm{e}$.

Based on this equation, it can be stated that hotel tax, restaurant tax and entertainment tax have a positive effect on local original revenue. 
Table 3. Partial Hypothesis Test Result

\begin{tabular}{|c|c|c|c|c|c|c|}
\hline \multicolumn{7}{|c|}{ Coefficients $^{\mathrm{a}}$} \\
\hline & & \multicolumn{2}{|c|}{ Unstandardized Coefficients } & \multirow{2}{*}{$\begin{array}{c}\text { Standardized } \\
\text { Coefficients } \\
\text { Beta }\end{array}$} & \multirow[b]{2}{*}{$\mathrm{t}$} & \multirow[b]{2}{*}{ Sig. } \\
\hline \multicolumn{2}{|c|}{ Model } & B & Std. Error & & & \\
\hline \multirow[t]{3}{*}{1} & (Constant) & 16,141 &, 887 & & 18,207 & 000 \\
\hline & Hotel Tax (X1) & ,269 & ,074 &, 562 & 3,643 &, 001 \\
\hline & Restaurant Tax (X2) & 184, &, 058 & ,332 & 3,144 &, 002 \\
\hline
\end{tabular}

Source: SPSS output, 2021

The significant value of the hotel tax variable of 0.001 is smaller than 0.05 indicating that the hotel tax variable has a significant effect on local revenue. This proves that the hypothesis which states, hotel tax has an effect on local revenue, is accepted. The significant value of the restaurant tax variable is 0.002 which is smaller than 0.05 indicating that the restaurant tax variable has a significant effect on local revenue. this proves that the hypothesis which states "restaurant tax has an effect on local revenue ", is accepted.

Table 4. Simultaneous Hypothesis Test Result

\begin{tabular}{|c|c|c|c|c|c|c|}
\hline \multicolumn{7}{|c|}{ ANOVA $^{\mathrm{a}}$} \\
\hline \multicolumn{2}{|c|}{ Model } & Sum of Squares & df & Mean Square & $\mathrm{F}$ & Sig. \\
\hline \multirow[t]{3}{*}{1} & Regression & 32,626 & 2 & 16,313 & 86,745 &, $000^{\mathrm{b}}$ \\
\hline & Residual & 12,600 & 67 &, 188 & & \\
\hline & Total & 45,226 & 69 & & & \\
\hline \multicolumn{7}{|c|}{ a. Dependent Variable: PAD (Y) } \\
\hline \multicolumn{7}{|c|}{ b. Predictors: (Constant), Pajak Restoran (X2), Pajak Hotel (X1) } \\
\hline
\end{tabular}

Source: SPSS output, 2021

Table 4 shows the results of the $\mathrm{F}$ test in this study, $\mathrm{F}$ count $(86,745)>\mathrm{F}$ table $(2.74)$ and significant $0.000<$ 0.05 . The hotel tax, restaurant tax and entertainment tax simultaneously have a significant effect on local revenue.

The coefficient of determination is used to measure the model's ability to explain variations in independent variables consisting of hotel tax and restaurant tax on the dependent variable. The results of the coefficient of determination in this study using SPSS version 26 (in table 5). The results of the coefficient of determination Table 5. Coefficient of Determination Test Result

\begin{tabular}{|l|r|r|r|r|}
\hline \multicolumn{7}{|c|}{ Model Summary $^{\mathrm{b}}$} \\
\hline Model & $\mathrm{R}$ & $\mathrm{R}$ Square & Adjusted R Square & Std. Error of the Estimate \\
\hline 1 &, $849^{\mathrm{a}}$ &, 721 &, 713 &, 4366 \\
\hline
\end{tabular}

test are known, the $\mathrm{R}$ value is 0.849 . This figure shows that the correlation between the dependent and independent variables is 0.849 . This means that there is a close relationship because the value is close to one (1).

The value of Adjust $R$ Square is 0.721 or $72.1 \%$. This shows the percentage contribution of hotel tax and restaurant tax to Local Revenue of $72.1 \%$. While the remaining $27.9 \%$ is influenced by other variables that are not included in this study. 


\subsection{Discussion}

\subsubsection{The Influence of Hotel Tax on Local Original Revenue}

Statistically, hotel tax has a t-count value of 3.643 with a t-table value of 1.996 and a significance value of 0.001 . The results show that the value of $t$ count $>t$ table $(3.643>1.996)$ and the hotel tax significance value is less than $0.05(0.001<0.05)$, then $\mathrm{Ho}$ is rejected and $\mathrm{H} 1$ is accepted. That is partially Taxes there is a significant effect on local revenue in the year 2016-2020. This shows that any increase or decrease in hotel tax revenue that occurs will affect local revenue.

Data from the Culture and Tourism Office of South Sumatra Province [12], the number of hotels in 14 regencies/cities continues to increase from 2016 to 2020. As the number of hotels grows, it can affect the level of hotel tax revenue. Hotel tax as a component of potential local tax revenue sources will also have an impact on increasing local revenue. The results of this study indicate that hotel taxes can affect the increase in local original revenue. The higher the hotel tax received Revenue.

\subsubsection{The Influence of Restaurants Tax on Local Original Revenue}

Statistically, restaurant tax has $\mathrm{t}$ value of 3,144 with a value of t table of 1.996 and 0.002 obtained significant value. The results show that the value of $t$ arithmetic > $t$ table $(3.144>1.996)$ and the significance value of the restaurant tax is less than $0.05(0.002<0.05)$, then Ho is rejected and $\mathrm{H}_{2}$ is accepted. That is partially Tax Restaurants there is a significant effect on revenue in the year 2016-2020. This shows that any increase or decrease in restaurant tax revenue that occurs will affect local revenue.

Based on data from the Department of Culture and Tourism of the Province of South Sumatra, the number of restaurants in the 14 regencies/cities studied increased during 2016-2020 [12]. The increase in the number of restaurants can affect the level of restaurant tax revenues. Restaurant tax as one of the components of local tax revenue sources whose revenue must be maximized because it will also have an impact on increasing local revenue.

The results of this study contradict [9] which states that restaurant taxes have no effect on Local Revenue. [10] states the same thing that the restaurant tax has no effect on local revenue. Currently, the tourism sector is able to make a major contribution to increasing local revenue, seen from hotel and restaurant tax contributions whose revenues reached Rp. 118 billion in [13]. The development of the restaurant business in South Sumatra makes restaurant tax revenue very promising as one of the sources of regional tax revenue that has the largest contribution in helping to increase local revenue so that it is expected to have a significant impact on each region.

\subsubsection{The Influence of Hotel Tax and Restaurants Tax on Local Original Revenue}

The calculated $F$ value is 86,745 with a significant level of 0.000 . The calculated $F$ shows a number that is greater than the $F_{\text {table }}$ or $(86,745>2.74)$ and the value is significantly smaller than 0.05 , which is 0.000 , then $\mathrm{H}_{\mathrm{o}}$ is rejected and $\mathrm{H}_{4}$ is accepted. This means that it can be concluded that the variables of hotel tax and restaurant tax simultaneously have a positive and significant effect on local revenue. The result of the next test, namely the analysis of the coefficient of determination, shows the Adjust $R$ Square value of 0.721 or $72.1 \%$. This means that the percentage contribution of the hotel tax and restaurant tax variable to local revenue can be said to be strong, namely $72.1 \%$, while the remaining $27.9 \%$ is influenced by other variables not included in this model.

Hotel tax revenues and restaurant taxes are types of local taxes whose revenues are increasingly being considered by the existence of several supporting components hotel tax and restaurant tax can be concluded to have an influence on regency/city local original revenue in South Sumatra Province. This is influential because hotel taxes and restaurant taxes are components of local tax revenues. Regions that have revenues from these taxes will greatly influence in increasing the amount of local original revenue in the regional government. [9] states that hotel tax and restaurant tax simultaneously have a significant effect on local original revenue. [10] states the same thing that hotel tax and restaurant tax together have a significant influence on local original revenue.

\section{CONCLUSION}

Hotel tax has a positive and significant effect on Local Revenue. This means that every increase in hotel tax will affect the increase in the value of local revenue. Hotel tax is one of the most important components in increasing local original revenue to meet the needs of a region. Restaurant tax has a positive and significant effect on local revenue. Restaurant tax is a tax whose receipts can affect local revenue. The number of business actors in the field of providing food and beverages always increases every year in the province 
of Sumatera. The increase in this amount can affect restaurant tax revenues which will contribute to Local Revenue. Hotel tax and restaurant tax together have a significant effect on local original revenue in regency/city governments in South Sumatra Province for the 2016-2020 period.

District/city governments in South Sumatra Province need to make efforts to optimize local tax collection to increase local revenue. Such as supervision and guidance and need to be active in socializing the importance of paying taxes in order to sustain local government activities. The community must play an important role in carrying out their responsibilities and increasing their compliance in paying taxes because this will provide feedback to the community with the results of development carried out by the government.

\section{ACKNOWLEDGMENT}

Thankfully acknowledges scientific discussion with our colleagues from Politeknik Negeri Sriwijaya, Indonesia. The authors would like to acknowledge the anonymous reviewers at the $5^{\text {th }}$ FIRST 2021 International Conference for the feedback of this paper. Also, thanks to the reviewers who provided feedback as part of this proceeding review process.

\section{REFERENCES}

[1] Martini, R., Pambudi, S. B., \& Mubarok, M. H. (2019). Analisis Kontribusi Retribusi Daerah terhadap Pendapatan Asli Daerah Kota Palembang. Publikasi Penelitian Terapan dan Kebijakan, II, 91-95.

[2] Republik Indonesia. (2004). Undang-undang Nomor 33 tentang Fiscal Balance Between the Central Government and Regional Governments.

[3] Martini, R., Agustin, R., \& Sari, K. R. (2020). Accrual Discretion Policy on Excess/Less Budget Financing at the Provincial Level. TEST Engineering \& Management, 82, 9925-9935.

[4] Republik Indonesia. (2009). Undang-undang Nomor 28 tentang Pajak Daerah dan Retribusi Daerah.
[5] Kementerian Kauangan Republik Indonesia. (t.thn.). Mengenal Pajak Daerah dan Retribusi Daerah. (2021). dari Kemenkeu: https://www.kemenkeu.go.id/publikasi/berita/me ngenal-pajak-daerah-dan-retribusi-daerah/

[6] Mahmudi. (2010). Manajemen Kinerja Sektor Publik. Yogyakarta: UPP STIM YKPN.

[7] Fikri, Z., \& Mardani , R. M. (2017). Pengaruh Pajak Hotel, Pajak Restoran, Dan Pajak Hiburan Terhadap Pendapatan Asli Daerah Kota Batu (Studi Kasus Pada Dinas Pendapatan Kota Batu Tahun 2012-2016). e-jurnal Riset Manajemen, 84-98.

[8] Lubis, D. F. (2017). Pengaruh Penerimaan Pajak Hotel, Pajak Restoran, Pajak Reklame dan Pajak Penerangan Jalan Terhadap Pendapatan Asli Daerah pada Pemerintahan Kabupaten Samalungun. Universitas Sumatera Utara, Fakultas Ekonomi dan Bisnis, Medan.

[9] Anggraini, R. (2017). Pengaruh Pajak Hotel, Pajak Restoran dan Pajak Hiburan Terhadap Peningkatan Pendapatan Asli Daerah Kabupaten Tulungagung Periode 2012-2016. Universitas Nusantara PGRI Kediri, Fakultas Ekonomi, Tulungagung.

[10] Lewasari, S. (2019). Pengaruh Pajak Hotel, Pajak Restoran dan Pajak Hiburan Terhadap Pendapatan Asli Daerah Kota Bandar Lampung Menurut Perspektif Ekonomi Islam. UIN Raden Intan Lampung, Fakultas Ekonomi Syariah, Lampung.

[11] Sanusi, A. (2014). Metodologi Penelitian Bisnis. Jakarta: Penerbit Salemba Empat.

[12] Dinas Kebudayaan dan Pariwisata Provinsi Sumatera Selatan. (2021). Statistik Pariwisata 2020. Edisi September 2020.

[13] Badan Pusat Statistik. (2021). Provinsi Sumatera Selatan Dalam Angka Tahun 2021. Edisi Februari 2021 